\title{
The plasma free amino acid dose-response technique: A proposed methodology for determining lysine relative bioavailability of rumen-protected lysine supplements
}

\author{
N. L. Whitehouse, ${ }^{*}$ C. G. Schwab, $†$ and A. F. Brito*1 \\ *Department of Agriculture, Nutrition, and Food Systems, University of New Hampshire, Durham 03824 \\ †Schwab Consulting LLC, Boscobel, WI 53805
}

\begin{abstract}
Estimates of Lys bioavailability of rumen-protected Lys (RP-Lys) supplements are often obtained using in vitro or 2-step in situ techniques, with little to no data determining efficacy and bioavailability in vivo. The objective of this study was to further evaluate and refine the use of the plasma free AA dose-response technique as a method for determining Lys relative bioavailability of RP-Lys supplements. Thirteen dose-response Latin square studies using 87 lactating, ruminally cannulated multiparous Holstein cows (days in milk from 55 to 315 and milk yield from 12 to $62 \mathrm{~kg} / \mathrm{d}$ at the start of the studies) were conducted to measure the relative bioavailability of RP-Lys supplements. Intestinal (1 study) and abomasal (12 studies) infusions of Lys ranged from 0 to $84 \mathrm{~g} / \mathrm{d}$, and experimental periods ranged from 4 to $21 \mathrm{~d}$. Basal diets were formulated to be adequate in metabolizable Met, but varied in predicted metabolizable Lys (5.04 to $6.81 \%$ of metabolizable protein). One to 4 daily blood samples were taken from the coccygeal vessels for 1 to 3 consecutive days in each period. Plasma Lys concentration in cows assigned to the control treatment $(0 \mathrm{~g} / \mathrm{d}$ Lys $)$ ranged from 1.83 to $5.21 \%$ of total plasma AA, whereas that from cows duodenally or abomasally infused with Lys ranged from 2.53 to $7.51 \%$ of total plasma AA. Results from studies involving more than 2 amounts of infused Lys confirmed linearity of response. The following variables were regressed against the plasma Lys dose-response slopes generated from the Lys infusion treatments to examine their effects on the magnitude of the slopes: plasma Lys concentration of the control diet, plasma Lys concentration at the greatest amount of infused Lys, net energy of lactation and metabolizable protein balances, metabolizable protein supply, days in milk, milk yield, milk concentrations of fat, true protein, and lactose, milk true protein
\end{abstract}

Received February 6, 2017.

Accepted August 10, 2017.

${ }^{1}$ Corresponding author: andre.brito@unh.edu yield, and dry matter intake. The variable having the greatest effect on the magnitude of the dose-response slope was the plasma Lys concentration at the greatest amount infused. The relative bioavailability of evaluated RP-Lys supplements using the plasma free AA dose-response technique ranged from 5 to $87 \%$. It was concluded that plasma free Lys increases in a linear fashion to increasing amounts of absorbed Lys and that the dose-response technique is an appropriate technique for evaluating RP-Lys supplements.

Key words: dairy cow, dose-response, lysine, relative bioavailability

\section{INTRODUCTION}

Lysine and Met are the 2 most limiting AA in typical North American dairy diets (NRC, 2001). Increasing Lys in MP to more optimal concentrations by postruminal infusion (King et al., 1991; Schwab et al., 1992) or by feeding a rumen-protected Lys (RP-Lys) supplement (Robinson et al., 2011; Lee et al., 2012) increased milk protein yield. Several RP-Lys supplements are available for the purpose of formulating rations for increased predicted concentrations of Lys in MP. Availability, variability in nutritional composition, digestibility, and cost of blood and fish meals have made RP-Lys supplements an attractive alternative, or a partial substitute, to these 2 RUP, Lys-rich supplemental protein sources. The RP-Lys supplements currently available on the market differ not only in terms of encapsulation technology, but also in size, density, and Lys concentration. Limited research indicates that the apparent availability of Lys to ruminants from RPLys supplements also varies widely (Robinson et al., 2011; Wu et al., 2012; Larson et al., 2015), making reliable estimates of Lys bioavailability essential when considering the use of these products. Although most suppliers provide estimates of Lys bioavailability for their RP-Lys supplements, these bioavailability values were not obtained using standardized techniques or methodologies. Without a standardized procedure 
for differentiating RP-Lys supplements under feeding conditions closer to commercial practices, producers and industry personnel have no reliable information to make decisions about which RP-Lys supplement to use based on price and amount of absorbable Lys.

The in situ technique that was developed to measure digestion of feed DM and its constituent organic fractions in the rumen and small intestine has been used to evaluate rumen-protected AA (RP-AA) supplements (Overton et al., 1996; Berthiaume et al., 2000; Koenig and Rode, 2001). The in situ technique has the advantage of obtaining independent estimates of ruminal escape and intestinal absorption of an AA for an RP-AA supplement from which an overall estimate of bioavailability can be calculated. Even though feedstuffs are subjected to ruminal fermentation and intestinal digestion with the in situ technique, several limitations exist, including (1) the absence of chewing and rumination effects; (2) potential discrepancy between nutrient disappearance from a bag and nutrient digestibility or absorption (Reynal et al., 2007); and (3) low reliability when testing fine or soluble supplements because they may be washed out of the bag (NRC, 2001; Robert, 2004, Kononoff et al., 2007). Ross et al. (2013) developed an in vitro assay for isolating the RUP fraction of feedstuffs and measuring its intestinal digestibility. This in vitro technique has been adapted for obtaining rates of ruminal degradation and estimates of intestinal digestibility of RP-AA supplements. Whereas the in vitro technique from Ross et al. (2013) has some decided advantages over the in situ method, the effect of exposing the RP-AA supplement to the ration before consumption, which has been shown to affect the integrity of some RP-Lys supplements (Ji et al., 2016) as well as chewing and rumination effects on bioavailability of AA from RP-AA, are eliminated. The Ross et al. (2013) in vitro technique has also not been published in a peer-reviewed journal, whereas the other techniques have.

In vivo techniques that have been used to determine AA bioavailability include the production response approach (Schwab et al., 2001), the area-under-the-curve method (Graulet et al., 2005), and the plasma free AA dose-response technique (Rulquin and Kowalczyk, 2003; Borucki Castro et al., 2008; Hanigan et al., 2009). The major limitation for the production response approach is being able to ensure a deficiency of the AA, in all animals, over the entire range of the treatment dosages that are used so that linearity in responses (e.g., concentration or yield of milk protein) are observed. For the area-under-the-curve technique, animals receive a single pulse dose of the RP-AA in amounts not normally encountered by the ruminal microbiota, which may limit supplement degradation. For studies where the plasma dose-response technique has been used (Rulquin and Kowalczyk, 2003; Borucki Castro et al., 2008; Hanigan et al., 2009), the limitation was that not all treatments (i.e., infused and fed doses of AA) were tested simultaneously within the same Latin square, thereby ignoring potential animal variation.

The plasma free Lys dose-response technique that we propose is a refinement of the plasma AA doseresponse developed by Rulquin and Kowalczyk (2003). The technique relies on a positive linear relationship between incremental amounts of infused or fed Lys and plasma Lys concentration. In fact, a linear relationship between incremental doses of infused Lys into the omasum, abomasum, or duodenum, and plasma Lys concentration has been reported (Rulquin and Kowalczyk, 2003; Borucki Castro et al., 2008; Hanigan et al., 2009). We hypothesized that increased plasma Lys concentration would reflect increased net absorption of Lys, and that changes in plasma Lys concentration could be used to calculate reliable estimates of Lys relative bioavailability (RBV) in RP-Lys supplements. The objective of our study was to further evaluate and refine the use of the plasma free AA dose-response technique as a method for determining Lys RBV of RP-Lys supplements, which was achieved by (1) confirming linearity of the response between incremental amounts of infused Lys and plasma Lys concentration; (2) examining cow-to-cow variation in plasma Lys concentration in response to increasing amounts of absorbed Lys and the consequent effect on RBV of Lys in RP-Lys supplements; (3) examining animal factors, covariate analysis, and carryover effects among other variables; and (4) comparing the RBV of RP-Lys supplements using the plasma free Lys dose-response technique.

\section{MATERIALS AND METHODS}

All procedures related to animal care were conducted with approval of the University of New Hampshire Institutional Animal Care and Use Committee (protocols no. 070902, 091201, 110502, 111103, 121201, and 130904). All studies were conducted at the University of New Hampshire Fairchild Dairy Teaching and Research Center (Durham, NH). Studies were conducted in 2001 (study 1), 2008 (study 2), 2010 (studies 3 and 4), 2011 (studies 5 and 6), 2012 (study 7), 2013 (studies 8 to 11), and 2014 (studies 12 and 13).

\section{Experimental Design and Treatments}

The data set used herein came from 13 Latin square studies that were conducted at the University of New Hampshire to calculate the RBV of Lys from 27 RP-Lys supplements. It is important to note that some of the 
RP-Lys supplements were prototypes and some commercially available, but due to confidentiality agreements we cannot identify or disclose all products tested. Studies were conducted as single $(\mathrm{n}=7)$ or replicated $(\mathrm{n}=6)$ Latin squares. Specifically, 1 study was designed as a $3 \times 3,5$ studies as $4 \times 4,5$ studies as $5 \times 5$, and 2 studies as $6 \times 6$ Latin square design. Milk yield, DMI, and plasma concentration of AA were measured in all 13 studies. Milk composition (fat, protein, lactose, and MUN) was measured in all studies except 3 and 4 . The RBV of Lys from all 27 RP-Lys supplements were calculated across the 13 studies. Details about replications and experimental conditions are presented in Table 1. Information about DMI, milk composition, and plasma concentration of AA for the infusion treatments are presented in supplemental tables (Supplemental Tables S1 to S20; https://doi.org/10.3168/jds.2017-12695).

In study 1, Lys was infused into the duodenum using duodenally cannulated cows following the procedure of Schwab et al. (1992), and all animals were injected with sometribove zinc suspension (Posilac; Protiva, St. Louis, MO) in the first day of each 14-d experimental period. In studies 2 to 13 , Posilac was not administered and Lys was infused into the abomasum using ruminally cannulated cows following the procedure of Gressley et al. (2006). The ingredient composition of the basal diets and the nutritional composition of individual feedstuffs are presented in Tables 2 and 3, respectively. Smartamine M (Adisseo USA Inc., Alpharetta, GA) was fed in all studies, with the exception of study 10, in which MetiPEARL (Kemin Industries Inc., Des Moines, IA) was used. The RP-Met supplements were fed to ensure that diets were Met-adequate according to the NRC (2001) so Met deficiency would not have adverse effects on the plasma AA profile (NRC, 2001). The infusion treatments consisted of Lys$\mathrm{HCl}(80 \%$ Lys) assuming a Lys bioavailability of $100 \%$ (Izquierdo et al., 1988; Chung and Baker, 1992) or Lys sulfate (50.7\% Lys), also assuming a Lys bioavailability of $100 \%$ (Smiricky-Tjardes et al., 2004). The infusion solutions were prepared daily at 1350 (study 1), 1530 (study 2), and at $1400 \mathrm{~h}$ (studies 3 to 13) by mixing Lys- $\mathrm{HCl}$ or Lys sulfate with $4 \mathrm{~L}$ of warm tap water. Cows assigned to the control treatment $(0 \mathrm{~g} / \mathrm{d}$ of infused Lys or fed RP-Lys) were infused with tap water only. Solutions were infused using peristaltic pumps (Manostat, Barnant Co., Barrington, IL; Masterflex, Cole-Parmer, Vernon Hills, IL). Pumps were turned off and the infusion lines disconnected during milking times for approximately 45 min per milking. Pumping

Table 1. Experimental design, DIM ( $\pm \mathrm{SD})$, amounts of Lys infused, period length, and regression parameters across 13 studies with tested rumen-protected Lys supplements ( $\mathrm{n}=224$ observations)

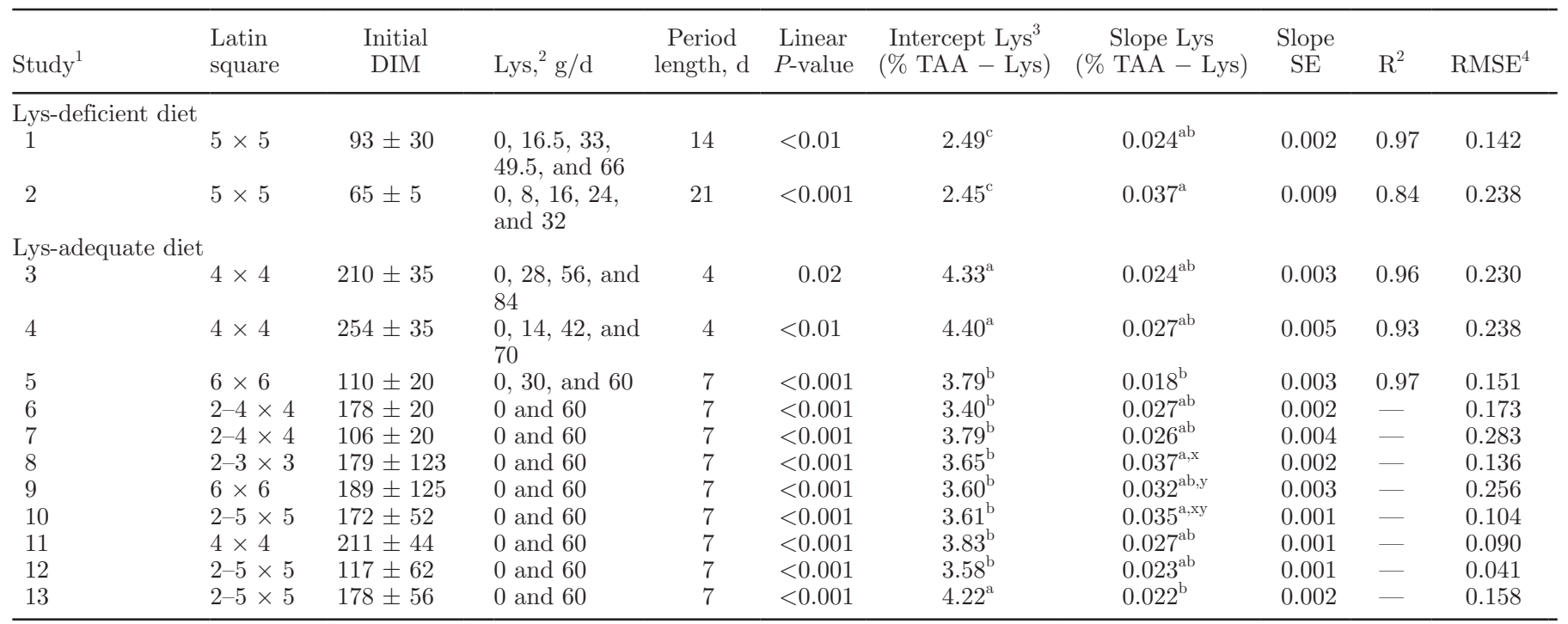

${ }^{\mathrm{a}-\mathrm{c}}$ Means within the same column differed at $P<0.05$.

${ }^{\mathrm{x}, \mathrm{y}}$ Slopes for these studies when analyzed separate from the other slopes, means within the same column differed at $P<0.04$.

${ }^{1}$ Studies were conducted in 2001 (study 1), 2008 (study 2), 2010 (studies 3 and 4), 2011 (studies 5 and 6), 2012 (study 7), 2013 (studies 8 to 11 ), and 2014 (studies 12 and 13).

${ }^{2}$ Lys dose infused (g/d) per $24.6 \mathrm{~kg}$ of DMI (study 1), $24.9 \mathrm{~kg}$ of DMI (study 2), and $22.7 \mathrm{~kg}$ of DMI (studies 3 to 13). The amounts of Lys (g/d) from rumen-protected Lys supplements fed were the same as infused Lys $(\mathrm{g} / \mathrm{d})$, except for study 5 , where the amounts fed were 0 , 30, 45, and $60 \mathrm{~g} / \mathrm{d}$ of Lys.

${ }^{3} \mathrm{TAA}=$ total AA.

${ }^{4} \mathrm{RMSE}=$ root mean squared error. 
rates $(175 \mathrm{~mL} / \mathrm{h})$ were adjusted and monitored to ensure uniform and complete daily administration of Lys. The RP-Lys supplements were mixed by hand for approximately $1 \mathrm{~min}$ with 1.0 or $1.5 \mathrm{~kg}$ of as-fed TMR in studies 1 to 6 and 7 to 13 , respectively, placed in rubber tubs, and fed 30 min before each of the 3 daily feedings. The TMR/RP-Lys mix not consumed within 15 min was administered to animals via the ruminal cannula. Body weights were measured on 2 consecutive days at the beginning and end of the studies using a hydraulic floor scale (Emery Winslow Scale Co., Seymour, CT), and BCS was assigned in 0.25-unit increments on a 1 to 5 scale (Ferguson et al., 1994) at the beginning and end of each experiment.

\section{Management of Cows and Feed Sampling and Analyses}

Cows were housed in a naturally ventilated tiestall barn, fed individually ad libitum with minimal orts (2 to $4 \%$ ), and had access to water throughout the duration of the studies. All rations were fed as TMR. Cows were milked 3 times daily at 0550,1350 , and $2150 \mathrm{~h}$ in study 1 , and twice daily at 0430 and $1530 \mathrm{~h}$ in studies 2 to 13. Milk weights were recorded during each milking. Cows were fed 3 times daily at 0600, 1400, and $2200 \mathrm{~h}$ in study 1 , and at 0500,1400 , and $2100 \mathrm{~h}$ in studies 5 to 13 , and twice daily at 0500 and $1500 \mathrm{~h}$ in studies 2 to 4 . Basal diets were fed for a minimum of 2 wk before the start of the studies and were the same as those fed during the experimental periods. Dry matter intake, milk yield, concentrations and yields of milk components, and concentration of plasma free AA $(\mu M)$ in studies 2,5 , and 7 to 13 were collected the week preceding the start of the experiments and were used as covariates in the statistical model.

Samples of TMR and orts were collected daily and composited by equal weight in each period for determination of DM. The NRC (2001) evaluation of all basal diets is presented in Table 2, and nutritional composition of individual feed ingredients in Table 3. Samples of corn and haycrop silages were collected daily in all 13 studies. Alfalfa hay (studies 2 to 6 ) was sampled by using a Hilti model TE 7-A drill fitted with a 40-cm long metal core sampler (Hilti North America, Tulsa, OK). Blood meal, Bergafat (fractionated palm fatty acids with a high proportion of palmitic acid; Berg + Schmidt America LLC, Libertyville, IL), and mineral mixes were sampled weekly. The individual feedstuffs used to make the concentrate mixes were sampled at the feed mill (Poulin Grain, Newport, VT) and sent to the University of New Hampshire Fairchild Dairy Teaching and Research Center. Ingredients used in studies 2 to 13 were freeze-dried (Labconco Model 5, Kansas City, MO) for $48 \mathrm{~h}$, whereas ingredients used in study 1 were dried to $88 \% \mathrm{DM}$ for a minimum of $12 \mathrm{~h}$ in a forced-air oven at $60^{\circ} \mathrm{C}$ (VWR Scientific, Radnor, PA). Samples were stored in air-tight glass jars until completion of each study and ground to pass through a 1-mm screen using a Wiley mill (Thomas Scientific; Arthur H. Thomas, Philadelphia, PA) before nutritional analysis.

Composites of each ingredient were shipped to a commercial laboratory (Dairy One Cooperative Inc., Ithaca, NY) for nutritional analyses according to the methods for DM (method 930.15; AOAC International, 2006), CP (method 990.03; AOAC International, 2006), NDF [Ankom Technology method 6 (amylase- and sodium sulfite-treated NDF in feeds-filter bag technique for A200; Ankom Technology, Fairport, NY; solutions as in Van Soest et al., 1991)], ADF [Ankom Technology method 5 (ADF in feeds-filter bag technique for A200; Ankom Technology); solutions as in method 973.18; AOAC International, 1998], ether extract (method 2003.05; AOAC International, 2006), and ash (method 942.05; AOAC International, 2006). Feeds were also analyzed for AA concentration using cation-exchange chromatography (cIEC-HPLC) coupled with postcolumn ninhydrin derivatization and quantitation and norleucine as the internal standard (method 982.30; AOAC International, 2016; University of Missouri Experimental Station Chemical Laboratories, Columbia, MO). Tryptophan was determined after alkaline hydrolysis and sulfur AA were analyzed after performic acid oxidation (method 988.15; AOAC International, 2016).

\section{Milk Sampling and Analyses}

Milk samples were collected at each milking during the last $3 \mathrm{~d}$ of each experimental period. No milk samples were taken for studies 3 and 4 . Samples were preserved in tubes containing 2-bromo-2-nitropropan-1,3 diol (Broad Spectrum Microtabs II; Advanced Instruments Inc., Norwood, MA), pooled by cow for each day according to daily milk weights, and refrigerated at $4^{\circ} \mathrm{C}$ until shipped for determination of fat, true protein, lactose, and MUN by mid-infrared reflectance spectroscopy (Dairy One Cooperative Inc.).

\section{Blood Sampling and Analyses}

Blood samples were collected $3 \mathrm{~h}$ after the morning feeding on d 10 in study $1 ; 3 \mathrm{~h}$ after the morning feeding at d 19 and 21 in study $2 ; 1.5,3,4.5$, and 6 $\mathrm{h}$ after the morning feeding on $\mathrm{d} 4$ in studies 3 and 4 ; and $2,4,6$, and $8 \mathrm{~h}$ after the morning feeding on 


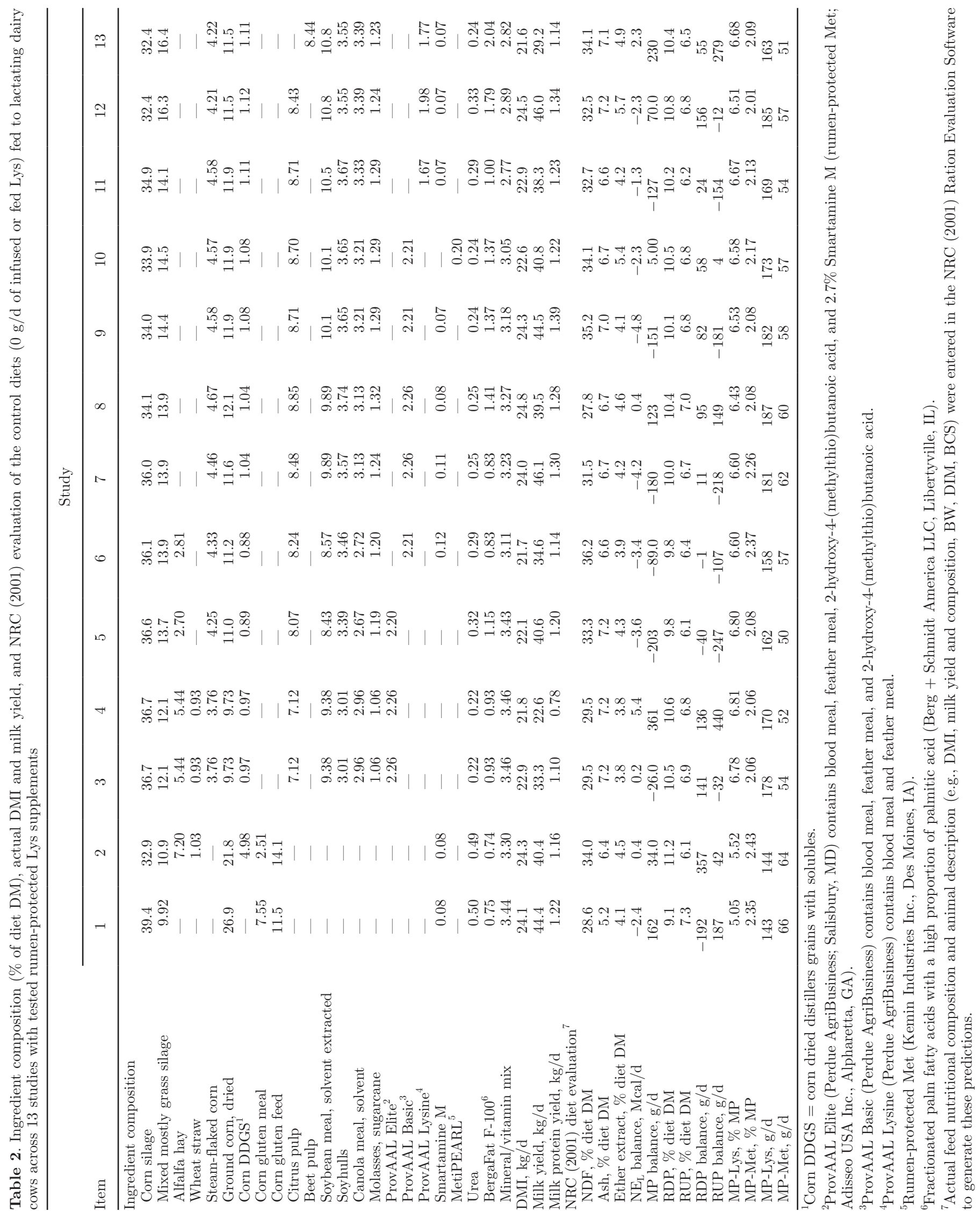


WHITEHOUSE ET AL.

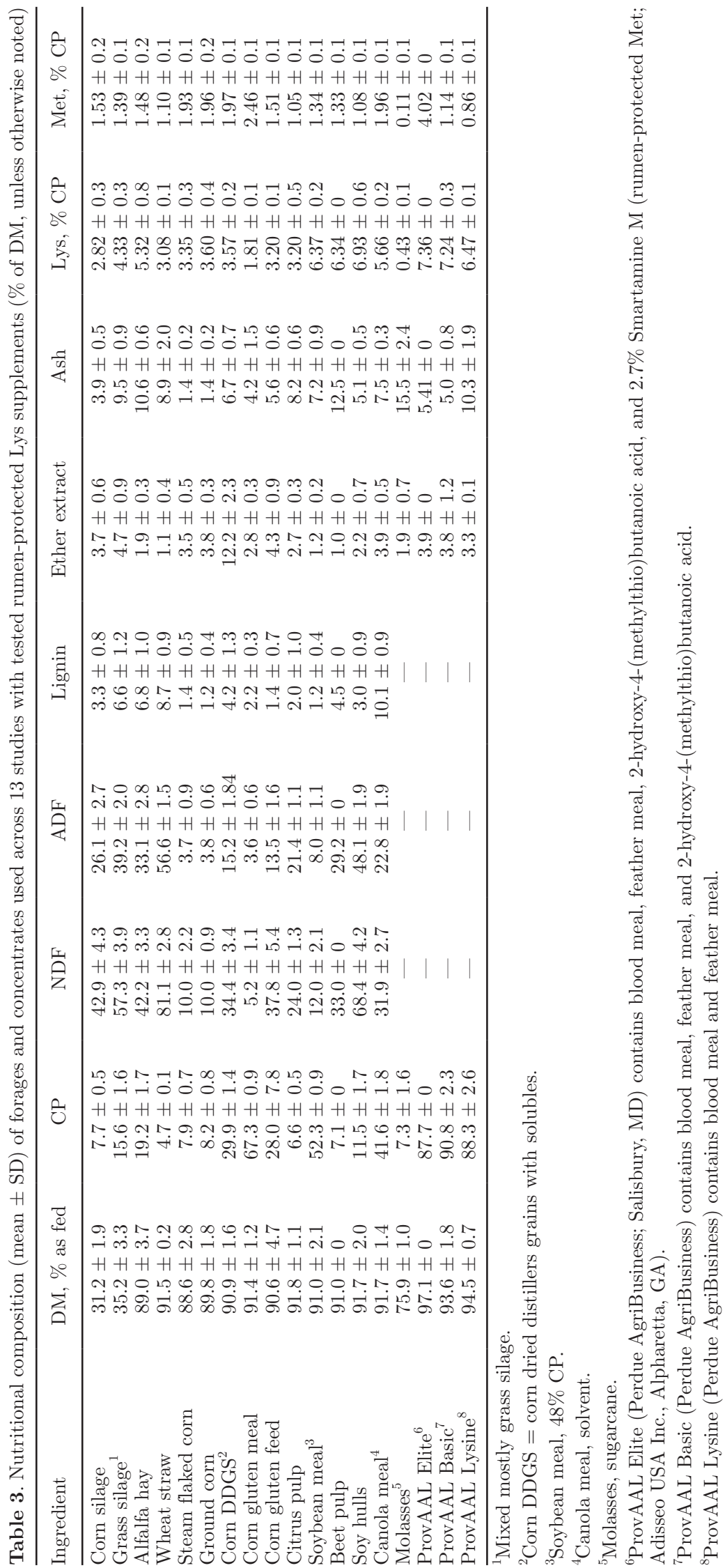


d 5, 6, and 7 in studies 5 to 13 . Blood was collected from the coccygeal vessels into $10-\mathrm{mL}$ vacutainer tubes (Monoject, Mansfield, MA) containing 15\% EDTA. Tubes were immediately placed on ice and centrifuged within 10 to $15 \mathrm{~min}$ at $1,200 \times \mathrm{g}$ for $20 \mathrm{~min}$ at $4^{\circ} \mathrm{C}$. A 4-mL aliquot of plasma from each sample was placed in glass test tubes containing $1.0 \mathrm{~mL}$ of $15 \%$ (wt/vol) 5 -sulfosalicylic acid. The tubes were allowed to sit for $10 \mathrm{~min}$ in the centrifuge before the second centrifugation $\left(1,200 \times g\right.$ for $20 \mathrm{~min}$ at $\left.5^{\circ} \mathrm{C}\right)$. An aliquot of 0.45 to $1.8 \mathrm{~mL}$ (depending on the study) of deproteinized plasma was removed, placed into $1.8-\mathrm{mL}$ cryovials, and stored at $-80^{\circ} \mathrm{C}$ for AA analysis using norleucine as the internal standard and cation-exchange chromatography (cIEC-HPLC) analysis by the University of Missouri Experimental Station Chemical Laboratories, following the procedures of Deyl et al. (1986) and Fekkes (1996). The deproteinized plasma collected at 2 different days in studies 1 and 2 were composited resulting in 1 sample per cow/period. The deproteinized plasma collected at 1.5 and $3 \mathrm{~h}$ after feeding in studies 3 and 4 were composited using the same pooling procedure done in studies 1 and 2; this procedure was repeated for deproteinized plasma collected at 4.5 and $6 \mathrm{~h}$ after feeding resulting in 2 samples per cow/period. In studies 5 to 13, the 4 deproteinized plasma samples collected daily were composited yielding 3 samples per cow/period.

\section{Statistical Analyses and Calculations}

The UNIVARIATE procedure of SAS (SAS version 9.4; SAS Institute, Inc., Cary, NC) was used to determine outliers in each experiment data set. A concentration of plasma Lys $(\mu M)>2.5$ standard deviations (SD) from the mean was considered an outlier and all associated AA data were removed from the statistical analyses.

Dry matter intake, milk yield, concentrations and yields of milk components, and plasma concentrations of free AA $(\mu M)$ were analyzed using the MIXED procedure of SAS (SAS version 9.4) according to the model

$\mathrm{Y}_{\mathrm{ijklm}}=\mu+\mathrm{L}_{\mathrm{i}}+\mathrm{P}_{\mathrm{j}}+\mathrm{S}_{\mathrm{k}}+\mathrm{lC}_{\mathrm{il}}+\mathrm{D}_{\mathrm{m}}+\mathrm{LD}_{\mathrm{im}}+\mathrm{E}_{\mathrm{ijklm}}$,

where $\mathrm{Y}_{\mathrm{ijklm}}=$ the dependent variable, $\mu=$ overall mean, $\mathrm{L}_{\mathrm{i}}=$ the fixed effect of the ith Lys infused and RP-Lys fed level, $\mathrm{P}_{\mathrm{j}}=$ the fixed effect of the jth period, $\mathrm{S}_{\mathrm{k}}=$ the fixed effect of the kth square (studies 6, 7, 8, 10 , and 12$), \mathrm{l}=$ the regression coefficient of the covariate $\mathrm{C}, \mathrm{C}_{\mathrm{il}}=$ the value of the covariate variable for the lth cow of the ith level (studies 2, 5, and 7 to 13 ), $\mathrm{D}_{\mathrm{m}}=$ the fixed effect of the mth day (studies 5 to 13 ), $\mathrm{LD}_{\mathrm{im}}=$ the fixed effect of the interaction between the ith level and the mth day, and $\mathrm{E}_{\mathrm{ijklm}}=$ the random residual error $\sim N(0, \sigma)$. The random effect of cow was used as the error term for the effect of infused Lys and fed RP-Lys levels on all dependent variables. Period and square (when replicated) were removed from all final models $(P \geq 0.25)$. Degrees of freedom were calculated using the Kenward-Roger option of the MIXED procedure of SAS. Least squares means (LSM) were determined for Lys infused or RP-Lys fed levels. Significant effects for Lys level was noted at $P \leq 0.05$. In studies 1 to 5 , linear, quadratic, and cubic effects were determined using the CONTRAST statement of SAS. The LSM for plasma Lys concentration from studies 1 to 5 were also subjected to the NLIN procedure of SAS for the threshold-plateau analysis. The data set from all 13 studies were run using a meta-analytical approach with study as a random effect. As the effect of study was not significant, it was not retained in the final regression models.

To generate the data to be used in the regression analysis (1) the total AA (TAA) concentration was calculated by adding Arg + His + Ile + Leu + Lys + Met + Phe + Thr + Trp + Val + Ala + Asn + Asp $+\mathrm{Cit}+\mathrm{Cys}+\mathrm{Gln}+\mathrm{Glu}+\mathrm{Gly}+\mathrm{Orn}+\mathrm{Pro}+\mathrm{Ser}$ + Tau + Tyr; (2) the plasma concentration ( $\mu M$ basis) of any individual AA in response to the infusion of Lys or fed RP-Lys that was significantly different from the plasma concentration of the same AA in the control treatment was removed from the TAA calculation for all treatments (i.e., control, infused, and fed); and (3) the plasma Lys data, expressed as a proportion of TAA subtracted from Lys, were then reanalyzed to generate the LSM that were used in the regression models (Equation 1):

$$
\begin{gathered}
\text { Plasma Lys, \% of TAA }- \text { Lys }= \\
\{\text { Lys }(\mu M) /[\text { TAA }(\mu M)-\text { Lys }(\mu M)]\} \times 100 .
\end{gathered}
$$

The LSM for all levels of infused Lys or fed RP-Lys were subjected to the REG procedure of SAS to generate intercepts, slopes, and coefficient of determination $\left(\mathbf{R}^{2}\right)$ using the slope ratio assay for studies 1 to 5 (Finney, 1978 ) and the 3-point assay (a derivative of the slope ratio assay; Littell et al., 1995) for studies 6 to 13.

In studies 5 to 7,12 , and 13, LSM were used to calculate RBV for RP-Lys supplements as (Equation 2)

$$
\begin{gathered}
\mathrm{RBV}=\text { slope of the RP-Lys fed/ } \\
\text { slope of Lys infusion } \times 100 .
\end{gathered}
$$

We assumed that the increase in plasma Lys concentrations with the infused or fed treatments was due to 
treatment effects, as all cows received the same basal diet within each study. We further assumed that the contribution of Lys from RUP, microbial protein, and endogenous protein was constant within each study. Confidence intervals (CI) for RBV were calculated by multiplying standard error of the mean $($ SEM $) \times 1.96$ \pm the slope for both Lys infusion or RP-Lys treatments. The upper limit CI was obtained by dividing the upper limit of RP-Lys by the upper limit of the Lys infusion treatment, whereas the lower limit CI was obtained by dividing the lower limit of RP-Lys by the lower limit of the Lys infusion treatment.

Variables such as plasma concentration of Lys expressed as a proportion of TAA in cows assigned to the control treatment $(0 \mathrm{~g} / \mathrm{d}$ of infused Lys), plasma concentration of Lys expressed as a proportion of TAA in cows assigned to the greatest Lys infusion amount, $\mathrm{NE}_{\mathrm{L}}$ and MP balances, MP supply, DIM, milk yield, milk concentrations of fat, true protein, and lactose, milk true protein yield, and DMI were regressed against the plasma concentration of Lys to assess their effects on the regression slopes.

In studies 2, 5, and 7 to 13 , data were analyzed using the MIXED procedure of SAS with and without the covariate term to determine whether the covariate should be retained in the final model. These data were also analyzed using the MIXED procedure of SAS to determine if there were any significant differences between the plasma concentration of Lys during the covariate period and the treatment with $0 \mathrm{~g} / \mathrm{d}$ of infused Lys or fed RP-Lys.

\section{RESULTS AND DISCUSSION}

\section{Determination of Lys Linearity in Plasma}

For the plasma free AA dose-response technique to be a widely accepted method for determining RBV of Lys from RP-Lys supplements, a positive linear response between increasing amounts of infused or fed Lys and plasma Lys concentrations must be unequivocally established. In fact, the plasma concentrations of Lys increased in a linear fashion in all 13 studies regardless of the number of infused doses of Lys used (Table 1), which agrees with previous research (Rulquin and Kowalczyk, 2003; Borucki Castro et al., 2008; Hanigan et al., 2009). No quadratic or cubic effects were observed for plasma Lys concentration as a result of multiple amounts of infused Lys or fed RP-Lys (Supplemental Tables S7-S11; https://doi.org/10.3168/jds.2017 -12695). The threshold-plateau model also indicated a linear response (data not shown). The effects of infused Lys on plasma AA concentration are shown in
Supplemental Tables S7-S20 (https://doi.org/10.3168/ jds.2017-12695).

\section{Period Length and Carryover Effects}

Period lengths of 14 and $21 \mathrm{~d}$ were used in studies 1 and 2, respectively (Table 1). Similar period lengths were used in previous Latin square experiments with Lys infusion (King et al., 1991; Schwab et al., 1992; Varvikko et al., 1999). Period length of $4 \mathrm{~d}$ was used in studies 3 and 4 , which is of similar length to that reported by Borucki Castro et al. (2008). Period length of $7 \mathrm{~d}$ was used in the remaining 9 studies (Table 1 ). Benefield et al. (2009) investigated whether length of experimental periods (i.e., 7 and $14 \mathrm{~d}$ ) used in a Latin square design would affect DMI, milk yield, and concentrations and yields of milk components when dairy cows were fed different amounts of 2 sources of RP-Met supplements. They concluded that there were no carryover effects with feeding RP-Met supplements for most production variables tested when using 7 - or 14-d periods (Benefield et al., 2009). The TMR/RPLys supplement mixes used in the current study were readily consumed by the cows in most feeding events, indicating minimal effect on animal acceptance. At the few occasions when a cow did not consume all of the TMR/RP-Lys supplement mix within $30 \mathrm{~min}$, it coincided with the first 2 feedings at the beginning of the experimental period. In those cases, less than 0.75 $\mathrm{kg}$ of the TMR/RP-Lys supplement mix was left and it was placed directly in the rumen via the cannula. The effects of infused Lys on DMI, milk yield, and milk components are presented in Supplemental Tables S1 to S6 (https://doi.org/10.3168/jds.2017-12695).

We compared the plasma concentration of Lys obtained during d 5 to 7 in cows assigned to the control treatment versus abomasal infusion of Lys or fed RP-Lys (Table 4). In 7 out of 9 studies presented in Table 4, no effect of day of sampling on plasma Lys concentration was observed, indicating that 7 -d periods appeared to be adequate. It is important to note that a quadratic effect was observed for plasma Lys concentrations in both control and Lys infusion treatments in study 7 , as well as in the Lys infusion treatment in study 9 . Because the methodology used in studies 7 and 9 was similar to that used in the remaining 7 studies, we cannot explain these quadratic effects associated with day of sampling. However, it seems that at least 3 consecutive days of blood samples should be taken to obtain a representative sample. Overall, our inferences about period length should be interpreted cautiously, as studies reported in Table 4 were not originally designed to test period length. 
We also investigated for potential carryover effects when using a 7-d period by comparing the plasma concentration of Lys obtained during the covariate period with that obtained from the control treatment during the sampling collection period (Table 5). Linear effects (decrease or increase) in plasma Lys concentration could have occurred in the event of carryover effects when cows were changed from the $60 \mathrm{~g} / \mathrm{d}$ of infused Lys or fed RP-Lys treatment to the control treatment or vice-versa. No difference in plasma Lys concentration was noted between covariate and sampling collection periods for the control treatment, suggesting no carryover effects when cows were switched from treatment to treatment.

Table 4. Effect of day of sampling on plasma Lys concentration [\% of plasma total AA (TAA) minus Lys $]^{1}$ during the last $3 \mathrm{~d}$ of the sampling period in lactating dairy cows receiving all Lys treatments (studies $5-7,12$, and 13$)$ or only the control treatment $(0 \mathrm{~g} / \mathrm{d}$ Lys $)$ and the abomasally infused Lys treatments (studies 8-10)

\begin{tabular}{|c|c|c|c|c|c|c|c|}
\hline \multirow[b]{2}{*}{ Item $^{2}$} & \multicolumn{3}{|c|}{ Plasma Lys } & \multirow[t]{2}{*}{ SEM } & \multicolumn{3}{|c|}{$P$-value ${ }^{3}$} \\
\hline & d 5 & d 6 & d 7 & & Day & Linear & Quadratic \\
\hline \multicolumn{8}{|l|}{ Study 5} \\
\hline $0 \mathrm{~g} / \mathrm{d}$ & 3.74 & 3.62 & 3.67 & 0.25 & 0.77 & 0.67 & 0.58 \\
\hline $30 \mathrm{~g} / \mathrm{d}$ Infusion & 4.49 & 4.36 & 4.62 & 0.21 & 0.65 & 0.65 & 0.43 \\
\hline $60 \mathrm{~g} / \mathrm{d}$ Infusion & 4.99 & 5.02 & 4.62 & 0.34 & 0.29 & 0.21 & 0.34 \\
\hline $30 \mathrm{~g} / \mathrm{d}$ AjiPro- $\mathrm{L}^{4}$ & 3.93 & 3.95 & 3.93 & 0.23 & 0.96 & 0.98 & 0.79 \\
\hline $45 \mathrm{~g} / \mathrm{d}$ AjiPro-L & 4.01 & 4.11 & 4.20 & 0.20 & 0.23 & 0.19 & 0.91 \\
\hline 60 g/d AjiPro-L & 4.18 & 4.18 & 4.00 & 0.27 & 0.18 & 0.12 & 0.35 \\
\hline \multicolumn{8}{|l|}{ Study 6} \\
\hline $0 \mathrm{~g} / \mathrm{d}$ & 3.34 & 3.42 & 3.50 & 0.25 & 0.53 & 0.27 & 0.99 \\
\hline $60 \mathrm{~g} / \mathrm{d}$ Infusion & 4.91 & 4.94 & 5.12 & 0.52 & 0.78 & 0.53 & 0.79 \\
\hline $60 \mathrm{~g} / \mathrm{d}$ Smartamine $\mathrm{M}^{5}$ & 4.74 & 4.78 & 4.89 & 0.25 & 0.69 & 0.41 & 0.79 \\
\hline $60 \mathrm{~g} / \mathrm{d}$ New AminoShure $\mathrm{L}^{6}$ & 3.51 & 3.66 & 3.70 & 0.26 & 0.15 & 0.13 & 0.33 \\
\hline \multicolumn{8}{|l|}{ Study 7} \\
\hline $0 \mathrm{~g} / \mathrm{d}$ & 3.66 & 3.96 & 3.74 & 0.15 & 0.10 & 0.55 & 0.04 \\
\hline $60 \mathrm{~g} / \mathrm{d}$ Infusion & 5.25 & 4.86 & 5.83 & 0.31 & 0.05 & 0.13 & 0.04 \\
\hline 60 g/d AjiPro-L & 4.31 & 4.31 & 4.26 & 0.08 & 0.80 & 0.56 & 0.78 \\
\hline $60 \mathrm{~g} / \mathrm{d}$ New AminoShure L & 3.98 & 3.88 & 4.03 & 0.10 & 0.39 & 0.66 & 0.19 \\
\hline \multicolumn{8}{|l|}{ Study 8} \\
\hline $0 \mathrm{~g} / \mathrm{d}$ & 3.69 & 3.61 & 3.60 & 0.25 & 0.73 & 0.50 & 0.67 \\
\hline $60 \mathrm{~g} / \mathrm{d}$ Infusion & 5.69 & 6.06 & 5.86 & 0.42 & 0.53 & 0.61 & 0.33 \\
\hline \multicolumn{8}{|l|}{ Study 9} \\
\hline $0 \mathrm{~g} / \mathrm{d}$ & 3.61 & 3.57 & 3.63 & 0.20 & 0.81 & 0.85 & 0.55 \\
\hline $60 \mathrm{~g} / \mathrm{d}$ Infusion & 5.32 & 5.93 & 5.25 & 0.29 & 0.47 & 0.81 & 0.02 \\
\hline \multicolumn{8}{|l|}{ Study 10} \\
\hline $0 \mathrm{~g} / \mathrm{d}$ & 3.56 & 3.65 & 3.64 & 0.18 & 0.32 & 0.22 & 0.38 \\
\hline $60 \mathrm{~g} / \mathrm{d}$ Infusion & 5.75 & 5.80 & 5.64 & 0.24 & 0.71 & 0.60 & 0.55 \\
\hline \multicolumn{8}{|l|}{ Study 11} \\
\hline $0 \mathrm{~g} / \mathrm{d}$ & 3.88 & 3.85 & 3.76 & 0.11 & 0.39 & 0.21 & 0.65 \\
\hline $60 \mathrm{~g} / \mathrm{d}$ Infusion & 5.52 & 5.36 & 5.55 & 0.34 & 0.47 & 0.85 & 0.24 \\
\hline \multicolumn{8}{|l|}{ Study $12^{7}$} \\
\hline $0 \mathrm{~g} / \mathrm{d}$ & 3.58 & 3.52 & 3.61 & 0.18 & 0.62 & 0.70 & 0.38 \\
\hline $60 \mathrm{~g} / \mathrm{d}$ Infusion & 5.14 & 5.10 & 5.20 & 0.18 & 0.92 & 0.81 & 0.74 \\
\hline $60 \mathrm{~g} / \mathrm{d}$ RP-Lys ${ }^{8}$ supplement A & 3.79 & 3.87 & 3.85 & 0.20 & 0.66 & 0.54 & 0.51 \\
\hline $60 \mathrm{~g} / \mathrm{d}$ RP-Lys supplement B & 4.00 & 3.93 & 3.90 & 0.20 & 0.23 & 0.10 & 0.71 \\
\hline $60 \mathrm{~g} / \mathrm{d}$ RP-Lys supplement C & 3.96 & 4.02 & 4.09 & 0.18 & 0.55 & 0.28 & 0.91 \\
\hline \multicolumn{8}{|l|}{ Study $13^{7}$} \\
\hline $0 \mathrm{~g} / \mathrm{d}$ & 4.05 & 4.04 & 4.10 & 0.16 & 0.85 & 0.65 & 0.73 \\
\hline $60 \mathrm{~g} / \mathrm{d}$ Infusion & 5.10 & 5.46 & 5.37 & 0.33 & 0.69 & 0.53 & 0.55 \\
\hline $60 \mathrm{~g} / \mathrm{d}$ RP-Lys supplement 1 & 4.76 & 4.62 & 4.73 & 0.17 & 0.83 & 0.87 & 0.56 \\
\hline $60 \mathrm{~g} / \mathrm{d}$ RP-Lys supplement 2 & 4.60 & 4.49 & 4.60 & 0.17 & 0.39 & 0.96 & 0.17 \\
\hline $60 \mathrm{~g} / \mathrm{d}$ RP-Lys supplement 3 & 4.64 & 4.53 & 4.64 & 0.13 & 0.21 & 0.98 & 0.18 \\
\hline
\end{tabular}

${ }^{1}$ Plasma Lys, $\%$ of TAA - Lys $=\{$ Lys $(\mu M) /[$ TAA $(\mu M)-$ Lys $(\mu M)]\} \times 100$ (Equation 1$)$.

${ }^{2}$ Only listed studies with $3 \mathrm{~d}$ of sampling were used; studies were conducted in 2011 (studies 5 and 6), 2012 (study 7), 2013 (studies 8 to 11), and 2014 (studies 12 and 13).

${ }^{3}$ Significance was declared at $P \leq 0.05$.

${ }^{4}$ AjiPro-L (Ajinomoto North America, Fort Lee, NJ).

${ }^{5}$ Smartamine M (Adisseo USA Inc., Alpharetta, GA).

${ }^{6}$ New AminoShure L (Balchem Corp., New Hampton, NY).

${ }^{7}$ Supplements provided by QualiTech Inc. (Chaska, MN).

${ }^{8} \mathrm{RP}$-Lys $=$ rumen-protected lysine. 
Table 5. Plasma concentration of Lys $\left[\%\right.$ of plasma total AA (TAA) minus Lys ${ }^{1}$ during the covariate period ( $3 \mathrm{~d}$ before the start of study) and sampling collection period (d 5 to 7 ) in lactating dairy cows assigned to the control treatment $(0 \mathrm{~g} / \mathrm{d}$ of Lys) across 8 studies with tested rumen-protected Lys supplements

\begin{tabular}{|c|c|c|c|c|c|c|c|c|}
\hline \multirow[b]{2}{*}{ Item $^{2}$} & \multicolumn{3}{|c|}{ Covariate period } & \multicolumn{3}{|c|}{ Sampling period } & \multirow[b]{2}{*}{ SEM } & \multirow{2}{*}{$\frac{P \text {-value }}{\text { Day }}$} \\
\hline & $\mathrm{d}-3$ & $d-2$ & $\mathrm{~d}-1$ & d 5 & d 6 & d 7 & & \\
\hline Study 5 & 3.48 & 3.50 & 3.73 & 3.74 & 3.62 & 3.67 & 0.25 & 0.35 \\
\hline Study 7 & 3.56 & 3.56 & 3.66 & 3.66 & 3.96 & 3.74 & 0.12 & 0.13 \\
\hline Study 8 & 3.56 & 3.70 & 3.52 & 3.68 & 3.62 & 3.60 & 0.21 & 0.43 \\
\hline Study 9 & 3.42 & 3.42 & 3.47 & 3.63 & 3.57 & 3.64 & 0.17 & 0.12 \\
\hline Study 10 & 3.50 & 3.50 & 3.56 & 3.56 & 3.65 & 3.64 & 0.18 & 0.30 \\
\hline Study 11 & 3.70 & 3.81 & 3.76 & 3.88 & 3.85 & 3.75 & 0.10 & 0.24 \\
\hline Study 12 & 3.51 & 3.55 & 3.62 & 3.57 & 3.52 & 3.61 & 0.20 & 0.84 \\
\hline Study 13 & 4.29 & 4.20 & 4.04 & 4.05 & 4.04 & 4.10 & 0.16 & 0.45 \\
\hline
\end{tabular}

${ }^{1}$ Plasma Lys, $\%$ of TAA - Lys $=\{$ Lys $(\mu M) /[$ TAA $(\mu M)-$ Lys $(\mu M)]\} \times 100$ (Equation 1$)$.

${ }^{2}$ Only listed studies where $3 \mathrm{~d}$ of sampling were used; studies were conducted in 2011 (studies 5 and 6), 2012 (study 7), 2013 (studies 8 to 11), and 2014 (studies 12 and 13).

${ }^{3}$ Significance was declared at $P \leq 0.05$.

\section{Effect of Experimental Conditions on Regression Slopes, Intercepts, and Variation}

The regression intercepts between infused Lys and plasma Lys concentrations were significantly lower in cows fed Lys-deficient diets (studies 1 and 2) than in those fed Lys-adequate diets (studies 3 to 13; Table 1), with dietary Lys supply relative to animal requirements determined by the NRC (2001), as shown in Table 2 . Within the 11 studies where cows were fed Lys-adequate diets, the intercepts of the regressions obtained in studies 3 and 4 were greater than those obtained in studies 5 to 13 (Table 1). Cows in studies 3 and 4 received the greatest amount of infused Lys and were late in lactation, producing the least amount of milk across all studies (Table 1), which may help explain the difference in intercept values between these 2 studies and the remaining 9 Lys-adequate experiments.

The $\mathrm{R}^{2}$ of the regression between infused Lys and plasma Lys concentration in the studies where more than 2 doses of Lys were infused or fed ranged from 0.84 (study 2) to 0.97 (studies 1 and 5; Table 1). We observed a positive linear increase in the plasma concentration of 3-methlyhistidine as the amount of infused Lys increased in study 2 (Supplemental Table S8; https://doi.org/10.3168/jds.2017-12695). Blum et al. (1985) suggested that an increase in plasma concentration of 3-methylhistidine could be used as an indicator of muscle protein degradation. Because cows in study 2 were in early lactation, they may have mobilized AA, including Lys, from muscle tissues, possibly affecting the relationship between infused and plasma Lys concentration. That AA mobilization may have occurred is supported by the observation that the predicted concentration of Lys in MP averaged $6.55 \%$ in the treatment with the greatest amount of infused Lys (i.e., 32 $\mathrm{g} / \mathrm{d}$ ), lower than the 7.1 to $7.2 \%$ MP-Lys recommended by the NRC (2001) to ensure Lys adequacy. Although diets in study 1 were also formulated to be Lys-deficient, the dietary concentration of Lys in MP averaged 6.76 and $7.15 \%$ in cows infused with 49.5 or $66 \mathrm{~g} / \mathrm{d}$ of Lys, respectively, which is closer to meeting the NRC (2001) recommendation. According to Lapierre et al. (2006), as protein supply increases in protein-deficient diets there is more gut catabolism of Lys and no change in its hepatic removal, but an increase in the uptake of Lys by the mammary gland occurs. This suggests that Lys-deficient diets are not recommended when using the plasma free AA dose-response technique to calculate RBV for RP-Lys supplements.

\section{Assessing the Need for Including all Treatments in the Same Latin Square}

We selected studies 8,9 , and 10 that were conducted in the same year and used cows fed forage sources harvested on similar dates to assess whether or not all treatments should be included in the same Latin square. Our data showed that the slope of the regression line was greatest in study 8 , intermediate in study 10 , and lowest in study $9(0.037,0.035$, and 0.032 , respectively; Table 1$)$. In addition, the mean $( \pm \mathrm{SD})$ of the individual slopes from the 86 cows that received incremental amounts of infused Lys across all 13 studies averaged $0.0275 \pm 0.0137$, thereby resulting in 16 and $14 \%$ of the cows having a slope below or above the $95 \%$ CI, respectively (data not shown). Thus, the difference in slopes among studies 8, 9, and 10, as well as the proportion of cows that were below or above the 95\% CI, reinforce our recommendation that all treatments should be included in the same Latin square to minimize the likelihood to over- or underestimate the RBV of RP-Lys supplements due to animal variation. Further justification for having all treatments in the 
Table 6. Relative bioavailability (RBV), CI, and CV values for 3 rumen protected-Lys supplements tested in study 13 as determined for each of the 10 cows that were used ${ }^{1}$

\begin{tabular}{|c|c|c|c|c|}
\hline Cow & Treatment & $\mathrm{RBV}, \%$ & CI, $\%$ & $\mathrm{CV}, \%$ \\
\hline \multirow[t]{3}{*}{1} & Supplement 1 & 58.1 & $46.9-69.3$ & 30.8 \\
\hline & Supplement 2 & 45.7 & $31.7-59.5$ & 36.1 \\
\hline & Supplement 3 & 38.3 & $22.1-54.5$ & 39.0 \\
\hline \multirow[t]{3}{*}{2} & Supplement 1 & 20.7 & $14.4-27.1$ & 20.3 \\
\hline & Supplement 2 & 12.7 & $6.8-18.6$ & 15.8 \\
\hline & Supplement 3 & 9.2 & $2.8-15.6$ & 15.7 \\
\hline \multirow[t]{3}{*}{3} & Supplement 1 & 36.4 & $28.6-44.2$ & 14.6 \\
\hline & Supplement 2 & 23.5 & $14.9-32.1$ & 14.5 \\
\hline & Supplement 3 & 27.9 & $19.2-36.6$ & 13.3 \\
\hline \multirow[t]{3}{*}{4} & Supplement 1 & 31.9 & $26.5-37.3$ & 12.6 \\
\hline & Supplement 2 & 15.8 & $7.7-23.9$ & 16.9 \\
\hline & Supplement 3 & 19.5 & $11.9-27.1$ & 17.8 \\
\hline \multirow[t]{3}{*}{5} & Supplement 1 & 38.9 & $34.1-43.7$ & 14.0 \\
\hline & Supplement 2 & 25.3 & $16.4-34.2$ & 17.7 \\
\hline & Supplement 3 & 16.5 & $6.7-26.3$ & 20.9 \\
\hline \multirow[t]{3}{*}{6} & Supplement 1 & 30.7 & $20.8-40.6$ & 18.9 \\
\hline & Supplement 2 & 24.1 & $16.1-32.1$ & 13.5 \\
\hline & Supplement 3 & 23.1 & $14.1-32.1$ & 16.3 \\
\hline \multirow[t]{3}{*}{7} & Supplement 1 & 60.9 & $55.1-66.7$ & 11.4 \\
\hline & Supplement 2 & 46.7 & $39.8-53.6$ & 16.4 \\
\hline & Supplement 3 & 46.0 & $35.2-56.8$ & 18.8 \\
\hline \multirow[t]{3}{*}{8} & Supplement 1 & 27.0 & $18.8-35.2$ & 16.5 \\
\hline & Supplement 2 & 21.4 & $13.1-29.7$ & 13.0 \\
\hline & Supplement 3 & 29.6 & $22.9-36.0$ & 12.6 \\
\hline \multirow[t]{3}{*}{9} & Supplement 1 & 21.0 & $13.7-28.3$ & 15.5 \\
\hline & Supplement 2 & 25.4 & $16.2-34.6$ & 16.6 \\
\hline & Supplement 3 & 32.0 & $26.4-37.6$ & 13.1 \\
\hline \multirow[t]{3}{*}{10} & Supplement 1 & 45.3 & $40.0-50.6$ & 11.3 \\
\hline & Supplement 2 & 25.4 & $19.4-31.4$ & 12.1 \\
\hline & Supplement 3 & 29.5 & $23.2-35.8$ & 11.9 \\
\hline
\end{tabular}

${ }^{1}$ The rumen protected-Lys supplements used in study 13 were supplied by QualiTech Inc. (Chaska, MN).

same Latin square is the inherent cow-to-cow variation. We selected study 13 , where 3 RP-Lys supplements were tested in a replicated $5 \times 5$ Latin square, to demonstrate how cow-to-cow variation affects RBV (Table 6). Overall, calculated RBV for all 3 RP-Lys supplements in study 13 were consistently greater in cows 1 and 7 and consistently lower in cow 2 compared with the remaining animals (Table 6).

We also used our data to further demonstrate that RBV could be seriously over- or underestimated if 1 Latin square is used for infused Lys and another for fed RP-Lys. For example, using the mean slope (0.01579; data not shown) for infused Lys from square 1 in study 13 and the mean slope (0.00904; data not shown) for fed RP-Lys from square 2 in the same study, the calculated RBV would be $57.3 \%$ compared with the previously determined RBV of $37.2 \%$ (Figure 1D). Likewise, using the mean slope (0.02820; data not shown) from square 2 for infused Lys and the mean slope (0.00602; data not shown) from square 1 for fed RP-Lys would lead to a calculated RBV of $21.3 \%$ compared with the previously determined RBV of $37.2 \%$ (Figure 1D). Thus, we recommend that all treatments (infused Lys and fed RP-Lys) are included in the same Latin square.

\section{Effect of Different Animal Variables on Regression Coefficients of Determination and Slopes}

The mean, range, SEM, and $\mathrm{R}^{2}$ generated by regressing the LSM of different variables against the slopes for the 13 studies are presented in Table 7 . The plasma Lys concentration at the greatest infusion amount regressed against the slope resulted in the greatest $R^{2}(0.32)$, whereas the $\mathrm{R}^{2}$ for the remaining variables were low (i.e., $\leq 0.088$ ). These low $\mathrm{R}^{2}$ indicate that variables such as the plasma concentration of Lys in cows assigned to the control treatment, DIM, milk yield, DMI, $\mathrm{NE}_{\mathrm{L}}$ and MP balances, MP supply, and milk true protein concentration and yield had minimal effect on changing the slope of the regression between incremental amounts of infused Lys and plasma Lys concentration.

\section{Assessing the Need for Including a Covariate Collection Period}

Studies 2, 5, and 7 to 13 were used to determine whether the covariate term should be retained in the final statistical model (Table 8). The covariate terms of studies 2, 5, and 11 were not significant, and the SEM of the regression slope between incremental amounts of 

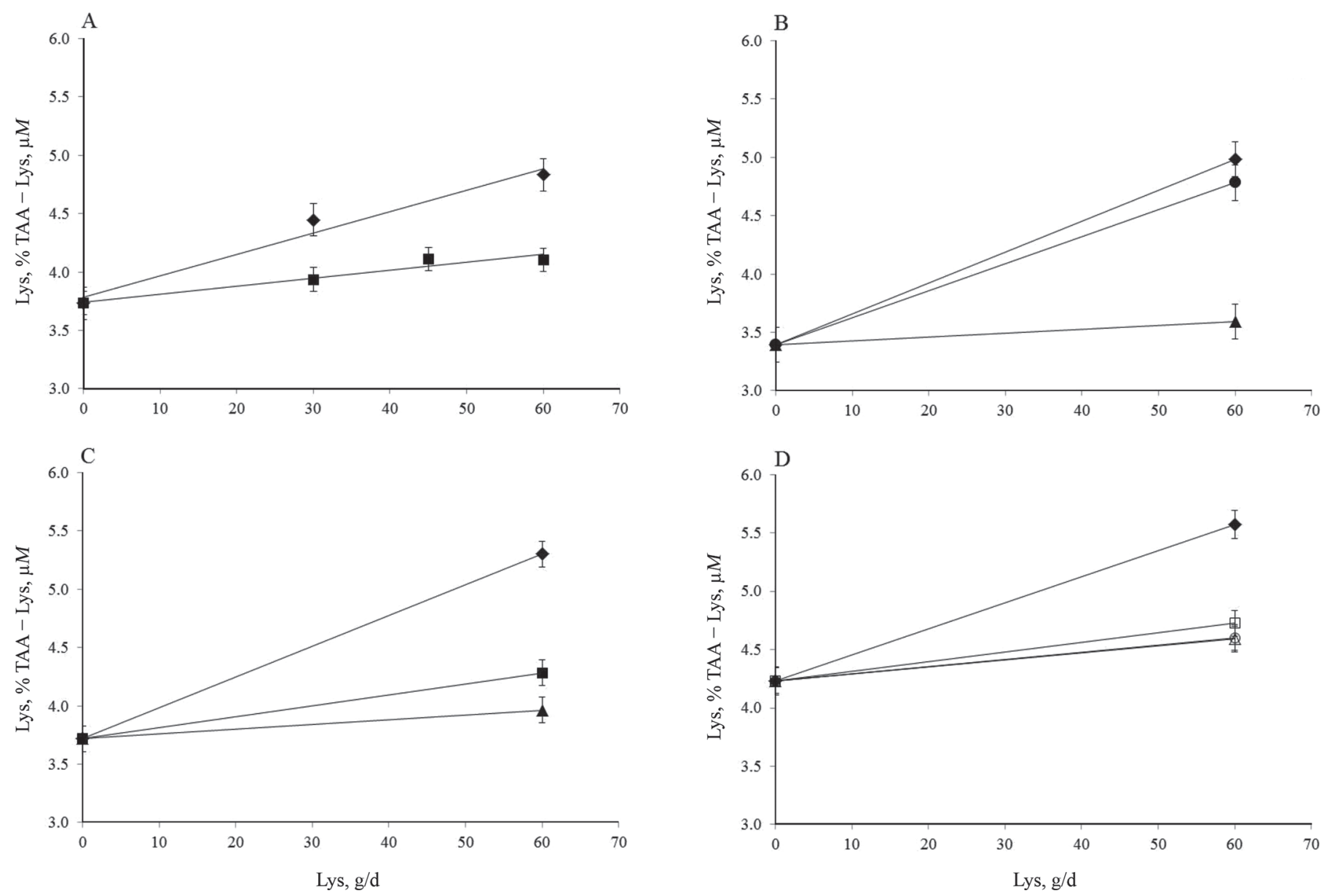

Figure 1. Effects of incremental amounts of infused Lys- $\mathrm{HCl}$ and fed rumen-protected Lys supplements on plasma concentration of Lys. Panel A shows the relationship between infused Lys-HCl $($ ) and fed AjiPro-L (Ajinomoto North America, Fort Lee, NJ; $\mathbf{\square})$ in lactating dairy cows offered a Lys-adequate diet (study 5). Infused Lys: $\mathrm{Y}=3.79+0.0183 \mathrm{x} ; P<0.001$, slope $\mathrm{SE}=0.003$, intercept $\mathrm{SE}=0.12, \mathrm{R}^{2}=0.97$. Fed AjiPro-L: $\mathrm{Y}=3.79+0.0068 \mathrm{x} ; P=0.001$, slope $\mathrm{SE}=0.002$, intercept $\mathrm{SE}=0.06, \mathrm{R}^{2}=0.93 ;$ relative bioavailability $=(0.0068 \div 0.0183) \times 100$ $=37.2 \%$. Panel B shows the relationship between infused Lys-HCl $\bullet$ ) and fed Smartamine ML (Adisseo USA Inc., Alpharetta, GA: $\bullet$ ) or New AminoShure-L (Balchem Corp., New Hampton, NY; $\mathbf{\Delta}$ ) in lactating dairy cows offered a Lys-adequate diet (study 6$)$. Infused Lys: Y $=3.40+$ 0.0265x; $P<0.001$, slope $\mathrm{SE}=0.002$, intercept $\mathrm{SE}=0.07$. Fed Smartamine ML: $\mathrm{Y}=3.40+0.0231 \mathrm{x} ; P<0.001$, slope SE $=0.001$, intercept $\mathrm{SE}=0.05$; relative bioavailability $=(0.0231 \div 0.0265) \times 100=87.2 \%$. Fed New AminoShure-L: $\mathrm{Y}=3.40+0.0033 \mathrm{x} ; P=0.05$, slope $\mathrm{SE}=$ 0.001 , intercept $\mathrm{SE}=0.06$; relative bioavailability $=(0.0033 \div 0.0265) \times 100=12.5 \%$. Panel $\mathrm{C}$ shows the relationship between infused Lys$\mathrm{HCl}(\boldsymbol{)})$ and fed AjiPro-L $(\boldsymbol{\square})$ or New AminoShure-L $(\boldsymbol{\Lambda})$ in lactating dairy cows offered a Lys-adequate diet (study 7$)$. Infused Lys: Y $=3.79$ $+0.0264 x ; P<0.001$, slope $\mathrm{SE}=0.004$, intercept $\mathrm{SE}=0.20$. Fed AjiPro-L: $\mathrm{Y}=3.79+0.0094 \mathrm{x} ; P=0.002$, slope $\mathrm{SE}=0.001$, intercept $\mathrm{SE}=$ 0.06 ; relative bioavailability $=(0.0094 \div 0.0264) \times 100=35.6 \%$. Fed New AminoShure-L: $\mathrm{Y}=3.79+0.0041 \mathrm{x} ; P=0.004$, slope SE $=0.001$, intercept $\mathrm{SE}=0.06$; relative bioavailability $=(0.0041 \div 0.0264) \times 100=15.5 \%$. Panel D shows the relationship between infused Lys-HCl $(\checkmark)$ and fed supplement $1(\square)$, supplement $2(\Delta)$, or supplement $3(\bigcirc$; QualiTech Inc., Chaska, MN) in lactating dairy cows offered a Lys-adequate $\operatorname{diet}($ study 13). Infused Lys: $\mathrm{Y}=4.22+0.0223 \mathrm{x} ; P<0.001$, slope $\mathrm{SE}=0.002$, intercept $\mathrm{SE}=0.06$. Fed supplement 1 : $\mathrm{Y}=4.22+0.0083 \mathrm{x}$; $P=0.001$, slope $\mathrm{SE}=0.0004$, intercept $\mathrm{SE}=0.02 ;$ relative bioavailability $=(0.0083 \div 0.0223) \times 100=37.2 \%$. Fed supplement $2: \mathrm{Y}=4.22+$ $0.0060 x ; P=0.001$, slope $\mathrm{SE}=0.0004$, intercept $\mathrm{SE}=0.02$; relative bioavailability $=(0.0060 \div 0.0223) \times 100=26.9 \%$. Fed supplement 3 : Y $=4.22+0.0061 \mathrm{x} ; P=0.001$, slope $\mathrm{SE}=0.0007$, intercept $\mathrm{SE}=0.03 ;$ relative bioavailability $=(0.0061 \div 0.0223) \times 100=27.4 \%$.

infused Lys and plasma concentration of Lys (\% TAA Lys) in studies 5 and 11 were not reduced by retaining the covariate term in the model. With the exception of study 9, all remaining studies with significant covariate terms (i.e., studies 7, 8, 10, and 13) were conducted as replicated Latin squares. In all these replicated studies, the SEM of the regression slope was reduced by keeping the covariate term in the statistical model. Therefore, we recommend the collection of covariate data followed by statistical analysis to determine whether or not the covariate term should be maintained in the final model.

\section{Units to Express Plasma Lys Concentration and Calculation of Relative Bioavailability}

Equation 1 was used to generate values of plasma Lys that were run in the regression models presented in Table 9. This equation decreased the SEM of the 
Table 7. Mean, range, and coefficient of determination of measured animal variables that were regressed against the slopes of the regressions between incremental amounts of infused Lys and plasma concentration of Lys

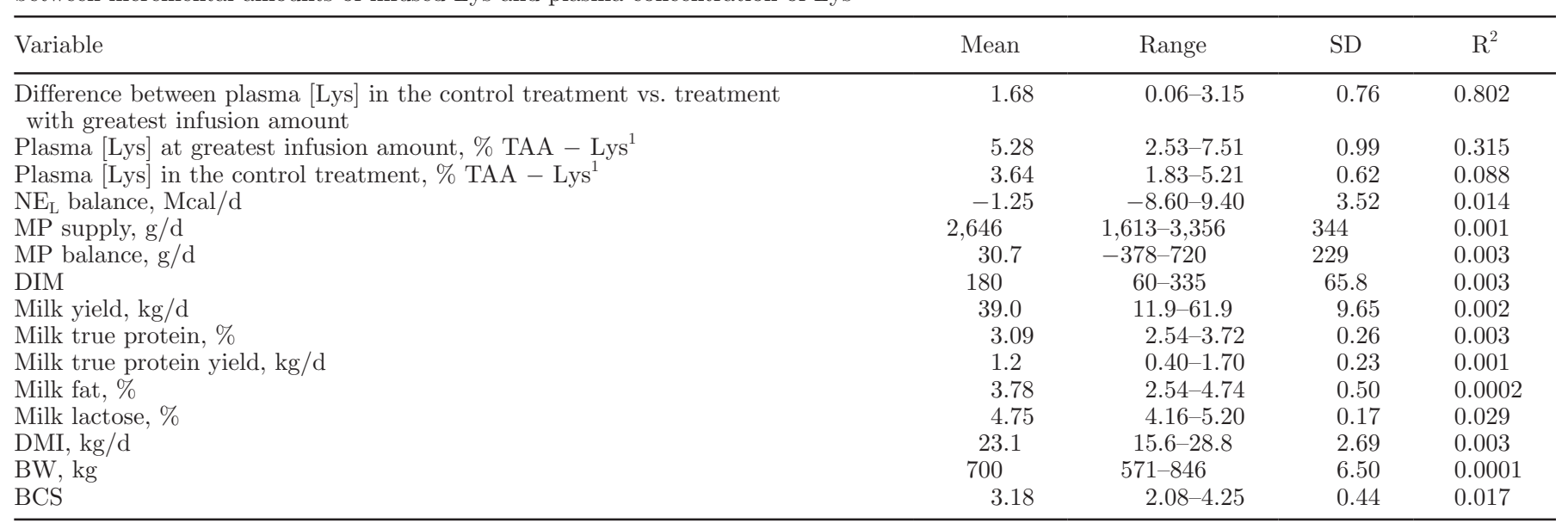

${ }^{1}$ Plasma Lys, $\%$ of total AA $($ TAA $)-$ Lys $=\{\operatorname{Lys}(\mu M) /[$ TAA $(\mu M)-$ Lys $(\mu M)]\} \times 100$ (Equation 1$)$.

slopes and intercepts, as well as CI and coefficient of variation in most regression models, except in studies 11 and 12, where the SEM were the same when plasma Lys concentration was expressed according to Equation 1 or as a proportion of TAA concentration (Table 9). Therefore, the RBV of different RP-Lys supplements were calculated by expressing plasma Lys concentration according to Equation 1. Furthermore, in study 12 , the RBV (calculated by expressing plasma Lys

Table 8. Significance of including the covariate term in the statistical model and SE for the regression slope between incremental amounts of infused Lys and plasma concentration of Lys [\% of plasma total AA (TAA) minus Lys $]^{1}$ when including or not the covariate term in the model across 9 studies with tested rumen-protected Lys supplements

\begin{tabular}{|c|c|c|c|c|}
\hline Item $^{2}$ & Slope & Covariate & $P$-value ${ }^{3}$ & $\mathrm{SE}$ \\
\hline \multirow[t]{2}{*}{ Study 2} & 0.0366 & Yes & 0.33 & 0.25 \\
\hline & 0.0369 & No & & 0.27 \\
\hline \multirow[t]{2}{*}{ Study 5} & 0.0181 & Yes & 0.27 & 0.16 \\
\hline & 0.0180 & No & & 0.16 \\
\hline \multirow[t]{2}{*}{ Study 7} & 0.0264 & Yes & 0.05 & 0.15 \\
\hline & 0.0265 & No & & 0.16 \\
\hline \multirow[t]{2}{*}{ Study 8} & 0.0374 & Yes & $<0.001$ & 0.11 \\
\hline & 0.0377 & No & & 0.32 \\
\hline \multirow[t]{2}{*}{ Study 9} & 0.0321 & Yes & 0.05 & 0.17 \\
\hline & 0.0320 & No & & 0.21 \\
\hline \multirow[t]{2}{*}{ Study 10} & 0.0352 & Yes & $<0.001$ & 0.09 \\
\hline & 0.0353 & No & & 0.17 \\
\hline \multirow[t]{2}{*}{ Study 11} & 0.0271 & Yes & 0.92 & 0.24 \\
\hline & 0.0271 & No & & 0.20 \\
\hline \multirow[t]{2}{*}{ Study 12} & 0.0232 & Yes & 0.09 & 0.09 \\
\hline & 0.0231 & No & & 0.10 \\
\hline \multirow[t]{2}{*}{ Study 13} & 0.0221 & Yes & 0.03 & 0.13 \\
\hline & 0.0221 & No & & 0.18 \\
\hline
\end{tabular}

${ }^{1}$ Plasma Lys, $\%$ of TAA - Lys $=\{$ Lys $(\mu M) /[$ TAA $(\mu M)-$ Lys $(\mu M)]\}$ $\times 100$ (Equation 1).

${ }^{2}$ Only listed studies where a covariate period sampling was used; studies were conducted in 2011 (study 5), 2012 (study 7), 2013 (studies 8 to 11), and 2014 (studies 12 and 13).

${ }^{3}$ Significance was declared at $P \leq 0.05$. concentration on a micromolar basis) did not differ significantly across 3 RP-Lys supplements (Table 10). However, when plasma Lys concentration was expressed as proposed in Equation 1, the RBV for supplements $\mathrm{B}$ and $\mathrm{C}$ were not different from each other but were greater than the RBV for supplement $\mathrm{A}$, thereby indicating that decreased variation (i.e., SE, CI, and CV) improved accuracy to detect RBV differences among supplements.

\section{Evaluation of RP-Lys Supplements Using the Plasma Free AA Dose-Response Technique}

The RBV for several RP-Lys supplements were calculated using Equation 2 and are presented in Figure 1 (A, B, C, and D). The RBV for AjiPro-L 1G (Ajinomoto North America Inc., Fort Lee, NJ), which is no longer on the market, averaged $37.2 \%$ (Figure 1A; study 5 ) and is close to the $40 \%$ bioavailability claimed by Ajinomoto (I. Shinzato, Ajinomoto Heartland Inc., Chicago, IL; personal communication) using the highly protected L-Arg procedure, as described by Swanepoel et al. (2010) and Robinson et al. (2011). Figure 1B (study 6) shows the evaluation of Lys in Smartamine ML (Adisseo France SAS, Antony, France) and New AminoShure-L (Balchem Corp., New Hampton, NY), both supplements which are no longer on the market. The RBV for Lys in Smartamine ML and New AminoShure-L averaged 87.2 and $12.5 \%$, respectively. We reevaluated AjiPro-L $1 \mathrm{G}$ and New AminoShure-L (Figure 1C; Study 7), which were initially evaluated in studies 5 and 6 , respectively. The RBV averaged $35.6 \%$ for AjiPro-L $1 \mathrm{G}$ and $15.5 \%$ for New AminoShure-L and were very similar to their original RBV calculations, thereby showing that the plasma free AA dose-response 
Table 9. Confidence intervals (between parentheses), SE, and CV for the slopes and intercepts of regression models for infused Lys across 13 studies with tested rumen-protected Lys supplements, and plasma concentration of Lys expressed as a proportion of total AA (TAA) or as proportion of TAA minus plasma Lys

\begin{tabular}{|c|c|c|c|c|c|c|c|c|c|c|}
\hline Item $^{1}$ & \multicolumn{5}{|c|}{ Plasma Lys (\% TAA) } & \multicolumn{5}{|c|}{ Plasma Lys $(\% \text { TAA }- \text { Lys })^{2}$} \\
\hline Study 1 & $\begin{array}{l}0.025 \\
(0.018-0.032)\end{array}$ & 0.003 & $\begin{array}{l}2.56 \\
(2.36-2.75)\end{array}$ & 0.10 & 3.96 & $\begin{array}{l}0.024 \\
(0.019-0.028)\end{array}$ & 0.002 & $\begin{array}{l}2.49 \\
(2.31-2.68)\end{array}$ & 0.10 & 3.73 \\
\hline Study 2 & $\begin{array}{l}0.034 \\
(0.013-0.056)\end{array}$ & 0.011 & $\begin{array}{l}2.40 \\
(2.00-2.80)\end{array}$ & 0.20 & 8.60 & $\begin{array}{l}0.037 \\
(0.018-0.055)\end{array}$ & 0.009 & $\begin{array}{l}2.45 \\
(2.10-2.81)\end{array}$ & 0.18 & 7.78 \\
\hline Study 3 & $\begin{array}{l}0.020 \\
(0.010-0.030)\end{array}$ & 0.005 & $\begin{array}{l}4.35 \\
(3.97-4.73)\end{array}$ & 0.20 & 3.36 & $\begin{array}{l}0.024 \\
(0.017-0.031)\end{array}$ & 0.003 & $\begin{array}{l}4.33 \\
(3.99-4.67)\end{array}$ & 0.18 & 3.07 \\
\hline Study 5 & $\begin{array}{l}0.016 \\
(0.008-0.026)\end{array}$ & 0.005 & $\begin{array}{l}3.70 \\
(3.43-3.96)\end{array}$ & 0.14 & 3.96 & $\begin{array}{l}0.018 \\
(0.012-0.025)\end{array}$ & 0.003 & $\begin{array}{l}3.79 \\
(3.55-4.03)\end{array}$ & 0.12 & 3.09 \\
\hline Study 6 & $\begin{array}{l}0.024 \\
(0.018-0.030)\end{array}$ & 0.003 & $\begin{array}{l}3.30 \\
(3.08-3.51)\end{array}$ & 0.11 & 3.81 & $\begin{array}{l}0.026 \\
(0.022-0.031)\end{array}$ & 0.002 & $\begin{array}{l}3.40 \\
(3.21-3.61)\end{array}$ & 0.10 & 3.47 \\
\hline Study 7 & $\begin{array}{l}0.023 \\
(0.012-0.034)\end{array}$ & 0.006 & $\begin{array}{l}3.65 \\
(3.26-4.03)\end{array}$ & 0.20 & 6.07 & $\begin{array}{l}0.025 \\
(0.017-0.033)\end{array}$ & 0.004 & $\begin{array}{l}3.79 \\
(3.45-4.12)\end{array}$ & 0.17 & 5.35 \\
\hline Study 11 & $\begin{array}{l}0.025 \\
(0.022-0.028)\end{array}$ & 0.001 & $\begin{array}{l}3.68 \\
(3.59-3.78)\end{array}$ & 0.05 & 1.97 & $\begin{array}{l}0.027 \\
(0.025-0.029)\end{array}$ & 0.001 & $\begin{array}{l}3.83 \\
(3.74-3.91)\end{array}$ & 0.04 & 1.65 \\
\hline Study 12 & $\begin{array}{l}0.024 \\
(0.023-0.025)\end{array}$ & 0.001 & $\begin{array}{l}3.45 \\
(3.40-3.50)\end{array}$ & 0.03 & 1.20 & $\begin{array}{l}0.026 \\
(0.025-0.07)\end{array}$ & 0.001 & $\begin{array}{l}3.58 \\
(3.53-3.62)\end{array}$ & 0.02 & 0.93 \\
\hline Study 13 & $\begin{array}{l}0.021 \\
(0.015-0.027)\end{array}$ & 0.003 & $\begin{array}{l}4.06 \\
(3.87-4.24)\end{array}$ & 0.10 & 3.81 & $\begin{array}{l}0.022 \\
(0.017-0.026)\end{array}$ & 0.002 & $\begin{array}{l}4.22 \\
(4.04-4.39)\end{array}$ & 0.09 & 3.21 \\
\hline
\end{tabular}

${ }^{1}$ Studies were conducted in 2001 (study 1), 2008 (study 2), 2010 (studies 3 and 4), 2011 (studies 5 and 6), 2012 (study 7), 2013 (studies 8 to 11 ), and 2014 (studies 12 and 13).

${ }^{2}$ Plasma Lys, $\%$ of TAA - Lys $=\{$ Lys $(\mu M) /[$ TAA $(\mu M)-$ Lys $(\mu M)]\} \times 100($ Equation 1$)$.

${ }^{3} \mathrm{CV}$ are for the regression model.

technique generates repeatable RBV calculations. Three RP-Lys supplements (Figure 1D; study 13) from QualiTech Inc. (Chaska, MN) were also evaluated, and 1 product is commercially available. The RBV averaged $37.2,26.9$, and $27.4 \%$ for supplements 1,2 , and 3 , respectively. As QualiTech was testing different encapsulation technologies (J. E. Garnet; QualiTech Inc., per- sonal communication), these results indicated that the plasma free AA dose-response technique is sensitive to changes in encapsulation matrices. Overall, we reported RBV ranging from 5.1 to $87.2 \%$ for the RP-Lys supplements evaluated in these studies, which reinforces the sensitivity of the plasma free AA dose-response technique to changes in encapsulation technologies adopted

Table 10. Plasma Lys concentration, expressed on an absolute basis $(\mu M)$ or as a proportion of total AA minus Lys (\% TAA - Lys), regression slopes, and relative bioavailability (RBV) obtained from cows infused with Lys-HCl or fed 3 rumen-protected Lys supplements in study $12^{1}$

\begin{tabular}{|c|c|c|c|c|c|c|c|c|}
\hline \multirow[b]{2}{*}{ Item } & \multicolumn{4}{|c|}{ Plasma Lys, $\mu M$} & \multicolumn{4}{|c|}{ Plasma Lys, \%TAA - Lys ${ }^{2}$} \\
\hline & Slope $^{3}$ & SE & $\mathrm{RBV}, \%(\mathrm{CI})$ & $\mathrm{CV},{ }^{4} \%$ & Slope $^{5}$ & $\mathrm{SE}$ & $\mathrm{RBV}, \%(\mathrm{CI})$ & $\mathrm{CV},{ }^{4} \%$ \\
\hline Supplement A & 0.108 & 0.026 & $17.1(9.7-23.7)$ & 2.47 & 0.004 & 0.0005 & $17.1^{\mathrm{b}}(14.0-19.7)$ & 1.17 \\
\hline Supplement B & 0.142 & 0.044 & $23.3(9.6-34.2)$ & 3.03 & 0.006 & 0.0006 & $24.6^{\mathrm{a}}(21.3-27.4)$ & 1.23 \\
\hline Supplement C & 0.170 & 0.042 & $27.4(15.0-37.7)$ & 3.76 & 0.007 & 0.0004 & $28.8^{\mathrm{a}}(27.8-29.7)$ & 1.34 \\
\hline
\end{tabular}

${ }_{\mathrm{a}, \mathrm{b}}$ Means in the same column differed at $P<0.05$ according to the Tukey test.

${ }^{1}$ Conducted in 2014.

${ }^{2}$ Plasma Lys, $\%$ of TAA - Lys $=\{$ Lys $(\mu M) /[$ TAA $(\mu M)-$ Lys $(\mu M)]\} \times 100($ Equation 1$)$.

${ }^{3}$ Slope differs from 0 at $P<0.01$.

${ }^{4} \mathrm{CV}$ are for the regression model.

${ }^{5}$ Slope differs from 0 at $P=0.02$. 


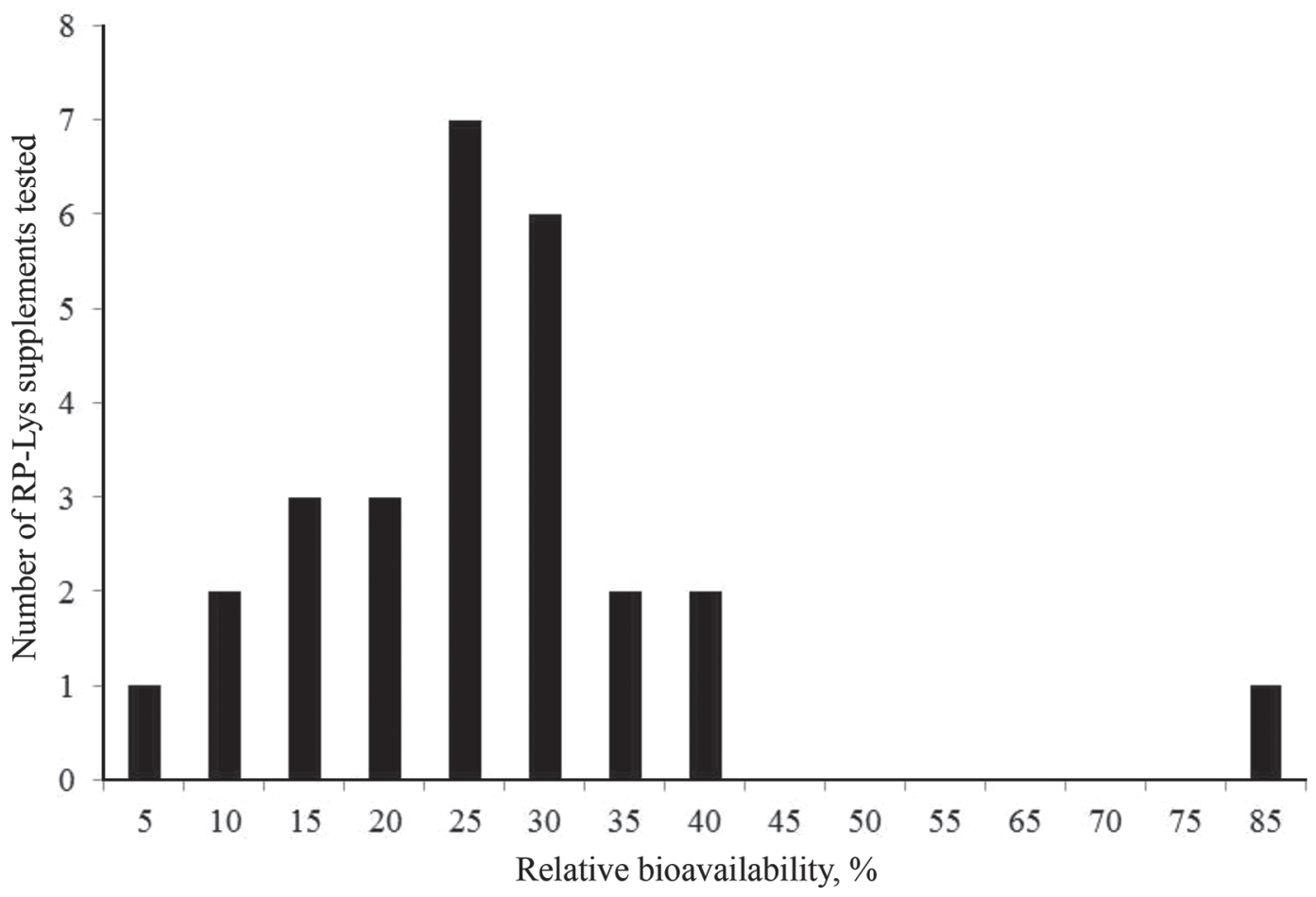

Figure 2. Relative bioavailability of 27 rumen-protected Lys (RP-Lys) supplements across 13 studies tested using the plasma free AA doseresponse technique.

Table 11. Recommendations for determining relative bioavailability (RBV) of rumen-protected Lys (RP-Lys) supplements using the plasma free AA dose-response technique

\begin{tabular}{|c|c|}
\hline Experimental design & Replicated Latin square with all treatments in the same square to minimize variation. \\
\hline Covariate period & Collect milk and blood samples during $3 \mathrm{~d}$ of the covariate period to obtain baseline data. \\
\hline Treatment & $\begin{array}{l}\text { It is recommended that } 3 \text { amounts (e.g., } 0,30 \text {, and } 60 \mathrm{~g} / \mathrm{d} \text { ) of abomasally or duodenally infused Lys and the } \\
\text { same amounts of fed Lys from RP-Lys supplements be used. }\end{array}$ \\
\hline Infusion & $\begin{array}{l}\text { Mix and dissolve Lys- } \mathrm{HCl} \text { in a minimum of } 4 \mathrm{~L} \text { of warm tap water, and infuse continuously into the abomasum } \\
\text { or duodenum. Pump infusion rates should be monitored regularly to ensure uniform and complete daily } \\
\text { administration of the infusate. }\end{array}$ \\
\hline Feeding RP-Lys & $\begin{array}{l}\text { Mix RP-Lys with } 1.5 \mathrm{~kg} \text { of TMR, place in plastic container with lids, and store at } 4^{\circ} \mathrm{C} \text { for } 8 \mathrm{~h} \text { before feeding to } \\
\text { expose the tested supplements to TMR conditions. Place the TMR/RP-Lys mix in rubber tubs and offer to the } \\
\text { cows } 30 \text { min before the actual feeding time. If the mix is not completely consumed within } 15 \text { min, place leftovers } \\
\text { directly in the rumen via cannula. }\end{array}$ \\
\hline Blood sampling & $\begin{array}{l}\text { Collect } 4 \text { blood samples (coccygeal or jugular veins) at 2-h intervals following the morning feeding during the last } \\
3 \mathrm{~d} \text { of each sampling period. }\end{array}$ \\
\hline Outlier analysis & Conduct a univariate analysis to determine outliers in the plasma concentration of AA, including Lys. \\
\hline Calculation of RBV & Divide the slope of the RP-Lys fed supplement by the slope of the infused Lys and multiply by 100 . \\
\hline
\end{tabular}


by different companies in the dairy industry (Figure 2). Our recommendations for determining RBV of RP-Lys supplements using the plasma free AA dose-response technique are outlined in Table 11.

\section{CONCLUSIONS}

The results from the studies presented herein support our hypothesis that a positive linear relationship exists between plasma Lys concentration and increasing amounts of Lys continuously infused into the abomasum or duodenum or fed as RP-Lys supplements. The refinements and improvements we propose helped to reduce experimental variation through decreased SEM, $\mathrm{CI}$, and coefficient of variation, as well as increased $\mathrm{R}^{2}$, thereby improving the accuracy of the plasma free AA dose-response technique for determining the RBV of Lys in RP-Lys supplements.

\section{ACKNOWLEDGMENTS}

We thank Adisseo (Commentry, France) for donation of Smartamine M and financial support, Perdue AgriBusiness (Salisbury, MD) for providing ProvAAL, and Kemin (Des Moines, IA) for providing MetiPEARL. Partial funding was provided by the New Hampshire Agricultural Experiment Station (Durham, NH). This is Scientific Contribution Number 2754. This work was partially supported by Hatch Multistate NC-1042 (Project Number NH00616-R; Washington, DC). We also thank the staff of the University of New Hampshire Fairchild Dairy Teaching and Research Center for animal care, feeding, and milking. A special thanks to the University of New Hampshire former graduate students (Shane Fredin, Scott Talbot, Trevor Beaudry, and André Pereira) for installing the abomasal infusion lines. Gratitude is extended to all University of New Hampshire undergraduates who supported animal care and sample collection, especially Elizabeth Fletcher, Adam Crowther, Gina Soule, Devan Chirgwin, Megan Blais, and Sarah Walstad. We also thank Shane Fredin (Adisseo USA Inc., Alpharetta, GA) and Heather Dann (The William H. Miner Agricultural Research Institute, Chazy, NY) for reviewing the manuscript and providing suggestions for improvement.

\section{REFERENCES}

AOAC International. 1998. Official Methods of Analysis, 16th ed. AOAC International, Arlington, VA.

AOAC International. 2006. Official Methods of Analyses, 18th ed. AOAC International, Gaithersburg, MD.

AOAC International. 2016. Official Methods of Analyses, 20th ed. AOAC Intertional, Gaithersburg, MD.
Benefield, B. C., R. A. Patton, M. J. Stevenson, and T. R. Overton. 2009. Evaluation of rumen-protected methionine sources and period length on performance of lactating cows within Latin squares. J. Dairy Sci. 92:4448-4455.

Berthiaume, R., H. Lapierre, M. Stevenson, N. Cote, and B. W. McBride. 2000. Comparison of the in situ and in vivo intestinal disappearance of ruminally protected methionine. J. Dairy Sci. 83:2049-2056.

Blum, J. W., T. Reding, F. Jans, M. Wanner, M. Zemp, and K. Bachmann. 1985. Variations of 3-methylhistidine in blood of dairy cows. J. Dairy Sci. 68:2580-2587.

Borucki Castro, S. I., H. Lapierre, L. E. Phillip, P. W. Jardan, and R. Berthiaume. 2008. Towards non-invasive methods to determine the effect of treatment of soya-bean on lysine availability in dairy cows. Animal 2:224-234.

Chung, T. K., and D. H. Baker. 1992. Apparent and true amino acid digestibility of a crystilline amino acid mixture and of casein: comparison of values obtained with ileal-cannulated pigs and cecectomized cockerels. J. Anim. Sci. 70:3781-3790.

Deyl, Z., J. Hyanek, and M. Horakova. 1986. Profiling of amino acids in body fluids and tissues by means of liquid chromatography. J. Chromatogr. 379:177-250.

Fekkes, D. 1996. State-of-the-art of high-performance liquid chromatographic analysis of amino acids in physiological samples. J. Chromatogr. B Biomed. Appl. 682:3-22.

Ferguson, J. D., D. T. Galligan, and N. Thomsen. 1994. Principal descriptors of body condition score in Holstein cows. J. Dairy Sci. 77:2695-2703.

Finney, D. J. 1978. Slope ratio assay. Pages 148-166 in Statistical Method in Biological Assay. 3rd ed. MacMillan Publishing Co. Inc., New York, NY.

Graulet, B., C. Richard, and J. C. Robert. 2005. Methionine availability in plasma of dairy cows supplemented with methionine hydroxy analog isopropyl ester. J. Dairy Sci. 88:3640-3649.

Gressley, T. F., S. M. Reynal, J. J. Olmos Colmenero, G. A. Broderick, and L. E. Armentano. 2006. Technical note: Development of a tool to insert abomasal infusion lines into cows. J. Dairy Sci. 89:3965-3967.

Hanigan, M. D., C. Vanderhoof, S. Garbade, O. Becvar, C. A. Umberger, and M. J. de Veth. 2009. In vivo determination of lysine bioavailability of rumen protected lysine in lactating dairy cows. J. Dairy Sci. 92(E-Suppl. 1):290. (Abstr.)

Izquierdo, O. A., C. M. Parsons, and D. H. Baker. 1988. Bioavailability of lysine in L-lysine-HCl. J. Anim. Sci. 66:2590-2597.

Ji, P., H. A. Tucker, R. E. Clark, M. Miura, and C. S. Ballard. 2016. Short communication: Effect on on-farm feeding practices on rumen protected lysine products. J. Dairy Sci. 99:1242-1246.

King, K. J., W. G. Bergen, C. J. Sniffen, A. L. Grant, D. B. Grieve, V. L. King, and N. K. Ames. 1991. An assessment of absorbable lysine requirements in lactating cows. J. Dairy Sci. 74:2530-2539.

Koenig, K. M., and L. M. Rode. 2001. Ruminal degradability, intestinal disappearance and plasma methionine response of rumenprotected methionine in dairy cows. J. Dairy Sci. 84:1480-1487.

Kononoff, P. J., S. K. Ivan, and T. J. Klopfenstein. 2007. Estimation of the proportion of feed digested in the small intestine of cattle consuming wet corn gluten feed. J. Dairy Sci. 90:2377-2385.

Lapierre, H., D. Pacheco, R. Berthiaume, D.R. Ouellet, C. G. Schwab, P. Dubreuil, G. Holtrop, and G.E. Lobley. 2006. What is the true supply of amino acids for dairy cows? J. Dairy Sci. 89(E. Suppl.):1-14.

Larson, H. E., I. Shinzato, M. Miura, I. J. Salfer, S. W. Fessenden, and M. D. Stern. 2015. Evaluation of three rumen-protected lysine sources produced in two different batches using a modified threestep in vitro procedure. J. Dairy Sci. 98(Suppl. 2):157. (Abstr.)

Lee, C., A. N. Hristov, T. W. Cassidy, K. S. Heyler, H. Lapierre, G. A. Varga, M. J. de Veth, R. A. Patton, and C. Parys. 2012. Rumen protected lysine, methionine, and histidine increase milk protein yield in dairy cows fed a metabolizable protein-deficient diet. J. Dairy Sci. 95:6042-6056.

Littell, R. C., A. J. Lewis, and P. R. Henery. 1995. Statistical evaluation of bioavailability assays. Pages $5-33$ in Bioavailability of $\mathrm{Nu}-$ 
trients for Animals: Amino Acids, Minerals, and Vitamins. C. B. Ammerman, D. H. Baker, and A. J. Lewis, ed. Academic Press, San Diego, CA.

NRC. 2001. Nutrient Requirements of Dairy Cattle. 7th Rev. Ed. Natl. Acad. Press, Washington, DC.

Overton, T. R., D. W. LaCount, T. M. Cicela, and J. H. Clark. 1996. Evaluation of a ruminally protected methionine product for lactating dairy cows. J. Dairy Sci. 79:631-638.

Reynal, S. M., I. R. Ipharraguerre, M. Liñeiro, A. F. Brito, G. A. Broderick, and J. H. Clark. 2007. Omasal flow of soluble proteins, peptides, and free amino acids in dairy cows fed diets supplemented with proteins of varying ruminal degradabilities. J. Dairy Sci. 90:1887-1903.

Robert, J. C. 2004. Metabolizable methionine optimization of dairy cow ration. Pages 223-254 in Recent Advances in Animal Nutrition. P. C. Garnsworthy and J. Wiseman, ed. Nottingham University Press, Nottingham, UK.

Robinson, P. H., N. Swanepoel, I. Shinzato, and S. O. Juchem. 2011. Productive responses of lactating dairy cattle to supplementing high levels of ruminally protected lysine using a rumen protection technology. Anim. Feed Sci. Technol. 168:30-41.

Ross, D. A., M. Gutierrez-Botero, and M. E. Van Amburgh. 2013. Development of an in vitro intestinal digestibility assay for ruminant feeds. Pages 190-202 in Proc. of the Cornell Nutrition Conference for Feed Manufacturers. East Syracuse, NY. Dept. Animal Science, Cornell University, Ithaca, NY.

Rulquin, H., and J. Kowalczyk. 2003. Development of a method for measuring lysine and methionine bioavailability in rumen-protected products for cattle. J. Anim. Feed Sci. 12:465-474.
Schwab, C. G., C. K. Bozak, N. L. Whitehouse, and V. M. Olson. 1992. Amino acid limitation and flow to the duodenum at four stages of lactation. II. Extent of lysine limitation. J. Dairy Sci. 75:3503-3518.

Schwab, C. G., N. L. Whitehouse, A. M. McLaughlin, R. K. Kadariya, N. R. St-Pierre, B. K. Sloan, R. M. Gill, and J. C. Robert. 2001. Use of milk protein concentrations to estimate the methionine bioavailability of two forms of 2-hydroxy-4-methylthio butanoic acid (HMB) for lactating cows. J. Dairy Sci. 84(Suppl.1):35. (Abstr.).

Smiricky-Tjardes, M. R., I. Mavromichalis, D. M. Albin, J. E. Wubben, M. Rademacher, and V. M. Gabert. 2004. Bioefficacy of Llysine sulfate compared to feed grade lysine- $\mathrm{HCl}$ in young pigs. J. Anim. Sci. 82:2610-2614.

Swanepoel, N., P. H. Robinson, and L. J. Erasmus. 2010. Amino acid needs of lactating dairy cows: Impact of feeding lysine in a ruminally protected form on productivity of lactating dairy cows. Anim. Feed Sci. Technol. 157:79-94.

Van Soest, P. J., J. B. Robertson, and B. A. Lewis. 1991. Methods for dietary fiber, neutral detergent fiber, and nonstarch polysaccharides in relation to animal nutrition. J. Dairy Sci. 74:3583-3597.

Varvikko, T., A. Vanhatalo, T. Jalava, and P. Huhtanen. 1999. Lacation and metabolic responses to graded abomasal doses of methionine and lysine in cows fed grass silage diets. J. Dairy Sci. 82:2659-2673.

Wu, Z., J. K. Bernard, R. B. Eggleston, and T. C. Jenkins. 2012. Ruminal escape and intestinal digestibility of ruminally protected lysine supplements differing in oleic acid and lysine concentrations. J. Dairy Sci. 95:2680-2684. 